\title{
Life Experiences of Javanese Women with Type-2 Diabetes Mellitus
}

\author{
Rosiana Eva Rayanti ${ }^{1}$, Apriliana Ayu Eka Saputri ${ }^{2}$ \\ \{rosiana.evarayanti@uksw.edu ${ }^{1}$; aes.apriliana@gmail.com ${ }^{2}$ \} \\ Faculty of Medicine and Health Sciences, Universitas Kristen Satya Wacana ${ }^{1,2}$
}

\begin{abstract}
The prevalence of diabetes women in Indonesia is higher than man. Javanese women with type 2 diabetes mellitus are vulnerable groups with regards to lower income, less education, and less access to health services. Purpose: the study was described life experiences in terms of medication behavior, emotional status, and family support of Javanese women with type 2 diabetes mellitus. A qualitative method through in-depth interview and observation was used. Two participants were widowed mothers who had type 2 diabetes mellitus for more than five years. They were 51 years old and registered in the Primary Health Center Ampel District, Boyolali Regency. Result: the participants had noncompliance with the type 2 diabetes mellitus medication, although they had comorbidities or complications. They felt emotional and self-blame. Their activities were limited due to their physical weakness. Also, the participants had not received social support from the family like what they expected. Conclusion: Social culture affected Javanese women when diabetes woman is dealing with type 2 diabetes mellitus.
\end{abstract}

Keywords: emotional status, family support, Javanese women, medication behavior, type 2 diabetes mellitus

\section{Introduction}

Type 2 diabetes mellitus (DM) is a metabolic disorder characterized by increased blood sugar due to insulin resistance. When fasting blood sugar more than $126 \mathrm{mg} / \mathrm{dL}$, it indicates DM. It occurs either when the pancreas does not produce enough insulin (a hormone that regulates blood glucose), or when the body cannot effectively use the insulin it produces[1]. The prevalence of DM in worldwide among people 20-79 years old was 463 million people (9.3\%) in 2019. This number is expected to increase to 578 million (10.2\%) in 2030 and 700 million (10.2\%) in 2045[2]. In Indonesia, the prevalence of DM is also increasing. In 2019, Indonesia was ranking number seventh country with the highest prevalence of DM in the world (10.7 million). It will reach 13.7 million in 2030 and 16.6 million[2][3]. Indonesia is predicted in the top 10 countries with highest number of people with DM. In worldwide, women with diabetes aged 20-79 years was slightly lower than the man $(9.0 \%$ vs $9.6 \%)$ [3]. However, the number is expected to increase in 2030 and 2045[3]. In another hand, the prevalence of Indonesian women $(1.21 \%)$ with DM was slightly over than men $(1,78 \%)$ in 2018[4].

Central Java Province had a prevalence of diabetes (1.6\%) more than the prevalence of Indonesia national level (1.5\%) in 2018[4]. Boyolali District is a region in Central Java. Diabetes was the second highest noncommunicable diseases after hypertension in Boyolali 
District[5], 26.3006 people were having diabetes. Data from Primary Health Center Ampel 1 showed the number of diabetes women ( 39 women) was more than men ( 26 men) in 2017.

According to the worldwide data prevalence of diabetes, the prevalence is increasing by age[3]. Diabetes risk is strongly associated with chronological aging and sex hormones[6]. Signs and symptoms of diabetes in the elderly are quite different from younger people[7]. They suffer from morbidity dan mortality compare with the elderly without diabetes. Furthermore, they have a high risk of cardiovascular disease, geriatric syndrome such as cognitive impairments, and functional disabilities. Diabetes women are more risk in the old age of getting diabetes, it related to the menopausal phase. Elderly women with diabetes become fragile or frail persons.

Women have a greater risk of diabetes mellitus compared to the man. Three factors are affecting Indonesian women's life, such as lower income, less education, and less access to health care. Women with lower income and less education tend to have less access to health care facilities. Since type 2 DM caused by a combination of genetic factors and a sedentary lifestyle, women need to be educated about genes, lifestyle, and environment that affect diabetes. Awareness of family history helps women getting an early diagnosis. Health education of prevention and management of type 2 DM from health practitioners can encourage women to minimize their risk of developing the condition and its complications.

Most women in Indonesia spent on unpaid care work, like housework and caring responsibilities[8]. Women work longer hours than men[9], an average of 50 minutes in developing countries[9]. Women of working age only have $50 \%$ of working in the labor force, rather than men $(77 \%)$. Women are more likely than men to be unemployed. It means most women have no access to have a high income. Indonesian women who were working is well under men. In 2018, there were only $49,15 \%$ of women who were more than 15 years old working. This prevalence was well under the man, it reached to 78.23\%[10]. An average of Indonesian women workers got income Rp2.398.674 whereas it was less than men's income per month[10].

Thus, women are having less education. The number of educated women was lower than men in 2018[10]. There were $32.53 \%$ of high school graduated women in 2018. Also, the literacy rate in women over 15 years $(93.99 \%)$ was lower than men $(97.30 \%)[10]$. It shows there is inequality in education between women and men, while other countries have an equality literacy rate. Despite education, women also have less access to health insurance. In Indonesia, women had health insurance only $64.47 \%$ in $2018[10]$. Health insurance help women access health care. Women often seek health care for regular health checking or treatment. Women had more health complain (32.58\%) rather than men (29.36\%). Moreover, women morbidity rate was higher than man. These conditions indicate that women are a vulnerable group.

Patients with type $2 \mathrm{DM}$ tend to have a low quality of life[11] and less support system[12]. Diabetes women perceive symptoms associate with the disease that affects women's function of roles and freedom. These conditions make their identity disregard as an individual. A family support system encourages diabetes women to undergo diabetes treatment. Diabetes women need discipline, motivation, and adherence to follow the diabetics' diets, physical activity, and medication. Sometimes, it leads to boredom and stress in patients. Some study found that women with type 2 diabetes often feels emotions such as anxiety[13], depression, stress, and diabetes distress[14].

Social culture can put pressure on a diabetes woman's life. Most of Boyolali resident are Javanese people, includes in Ampel sub-district. Diabetes patients in Primary Health Center Ampel 1 mostly from the Javanese tribe. In Java culture, women obey the Javanese 
sociocultural values, includes their role in family and society. Javanese women are mindful of their nature as women. Javanese women define, regulate, and guide their behavior and life choices [15]. Role of Javanese women in society associates with domestic activities. Javanese women take care of the family member (husband and children)[16]. The family concept is precious in java society. The purpose of this study was to describe life experiences in terms of medication behavior, emotional status, and family support of Javanese women with type 2 diabetes mellitus.

\section{Method}

This research was qualitative with case studies among two widowed women. Participants were 51 years old, Javanese, and residents in Boyolali, Central Java. The first participant had a daughter, meanwhile, the other participant had three sons. Each of the participants owned a small grocery shop with uncertain income. They were diagnosed by a physician from Primary Health Center Ampel 1 sub-district, Boyolali Regency. They had type 2 diabetes mellitus for more than five years. Participants had comorbidities such as hypertension, visual disturbance, neurological disorders, and post-operate scar. Data collection used in-deep interview and observation. Data analysis was data reduction, data display, conclusion drawing, and verification[17].

\section{Result and Discussion}

\subsection{Medication Behaviour}

The participants were undergoing diabetes treatment. Data from Primary Health Center Ampel 1 sub-district, Boyolali Regency showed the two participants was having type 2 diabetes mellitus for five years. A daughter of participant 1 and a sister of participant 2 who suggested and motivated the participants to get diabetes treatments in health service.

In the early five years, both participants followed the physician's prescription and took diabetes medication regularly. Aside from oral medication, the first participant got an insulin injection. They also had comorbidities after having type 2 diabetes mellitus. However, after five years, they exhausted to take the medicine for type 2 diabetes mellitus. Participant 1 said "I have been bored for years of medicine. I traumatized when I did insulin injection" She had a post-operate scar, so she sought a nurse from Primary Health Center Ampel 1 sub-district to do wound care at her home. Also, she felt itching, tingling, and experience of visual impairment.

While the other participant mentioned, "I am afraid to take medicine because my blood sugar can drop drastically." She also mentioned that she had pain on her back, it was a lump. Meanwhile, the second participant was at the risk of diabetic gangrene as diagnosed by a physician. She was noncompliant with the medication, even though she knew she must take care of her blood sugar level.

Both participants took the medicine or sought the treatment if they felt unwell. Both participants worried about their condition, especially when their health worsens. However, they still took the medication when they need, ignoring the physician's prescription health behavior. 
Diabetes Mellitus is a chronic disease in long-term treatment. Medication adherence to diabetes women is needed. Taking medication regularly reduce the development or progression of the complications of diabetes emphasizes the need for good glycaemic control [18]. However, Javanese women with type 2 DM generally seek help when they have DM complications[15]. When they can perform their everyday activities, they seldom treating the disease. Less adherence to medication or uncontrolled blood sugar levels is associated with increased diabetes complications[19]. Also, many diabetes patients have a higher rate of lower limb amputations. Also, those participants at aged of pre-menopause. They are riskier to have complications and comorbidities.

Factors related to poor medication adherence of diabetes patients are lower education levels, and lower incomes[18]. Two participants had a low education level; they did not graduate from elementary school. They have limited information about the disease. Lack of information makes the participants ignore the physician's prescription. Moreover, as Javanese widowed women, they were working for living. They earned uncertain money from small groceries shop. They also did domestic work at home. They spent their time working and household rather than focus on diabetes treatment.

\subsection{Emotional Status}

Participants are emotionally after getting type 2 diabetes mellitus. The first participant said, "after having diabetes, I had a physical limitation, so I rarely involved actively in activities surrounding." She thought, type 2 diabetes mellitus as the main problem of her life. She felt weakness, particularly when her blood sugar level dropped. She depressed and anxious due to her illness which caused vision problems and neurological disorders. She surrendered to God. She had been angry with her family for not helping her immediately when she was sick. She thought her siblings did not pay attention to her. However, she tried to accept this situation.

Thus, the second participant also had a limitation, she just sat at home every day. She blamed herself, she had diabetes because of her unhealthy life and diet. She stated "I am still grateful for God because God still gives me a chance to replace my mistakes. I have diabetes because my unhealthy behavior." Also, she worried if she would be amputated at any time. She regretted. When she interacted with other family members who are living together, she felt irritable. Therefore, she got angry and frustrated easily when provoked by her daughter-inlaw. She slammed the plate or glass in front of her daughter-in-law. She said, "I anxiety with my life and feel careless."

Javanese women with diabetes claim it is a submission to God. They feel the type 2 DM is just another misfortune and hardship in life that one must experience and endure readily[15]. They accepted the diabetes mellitus as a fate from God. Pitaloka and Hsieh found that Javanese women believe that illness as God's will. Submission to the will of God, a higher power, represents the highest stage of faith in Javanese beliefs[15].

Diabetes women have depression, anxiety, and disease-related distress. These feeling is arising when the diabetes women poorly coop the depressive symptoms of diabetes. After having diabetes, the participants had physical weakness and spent time mostly at home. Lower income, lack of information and marital status as widow tends to make the participants have low quality of life. Diabetes women had poorer quality of life compared to men, moreover, diabetes men reported higher rates for supportive coping[14]. Diabetes-related distress stems from concerns or worries associated with living with the condition of diabetes[14]. Stress stimulates the release of various hormones, which can result in elevated blood glucose levels[20]. 


\subsection{Family support}

Participants expected their family to be with them and give motivation. The first participant said "My family does not take care of me. I had a brother, but he also not paying attention to me. "She just relied on her daughter. Although the other participant had three sons, she felt that only her sons, who were out of town, had supported her in the past five years. She said, "my sons give money and motivation. But my youngest son, who was lived with me, not support me at all. "

Participants thought they have not received social support from their families like what they expected. Social support is the existence, willingness, or concern of reliable people individuals who receive social support from the family, the conditions will be better than those who do not[14]. Support from the family provides an emotional bond and strength for DM sufferers to deal with their illness and free from depression. Increased social support was inversely related to emotional distress[14]. Also, family support improves the adherence of diabetes medication, and diet, increase motivation and prevent stress, that will ultimately affect blood sugar control and improve the quality of life of diabetes patient[21].

Both participants were widowed women. Married and widowed women have different level in Java society. A widower comprises a major disadvantaged social grouping within contemporary Indonesian society[22]. Mostly married women obtain financial support from a husband. In losing their husbands, who would have been their main source of financial support, these women are more likely to become dependent on their children or the state. This dependence is caused because women would not have worked or would have spent fewer years in the labor force because they would have needed to provide care to their families[23]. Widower often experiences economic hardship and structural discrimination because of its ambiguous legal status[22]. Uncertain marital status makes the participants more vulnerable. Economic and social difficulties experienced by unmarried women in Javanese society, particularly those with dependent children.

\section{Conclusion}

Life experiences of Javanese women with type 2 diabetes mellitus are affected by social culture. Two participants are widowed, had diabetes complications, lower income, and less educated. They modify their medication behavior, feel emotional, and self-blame. Also, they hope their family will take care of them, but not all members of the family pay attention and care for them. Two participants need encouragement from the family to encounter diabetes treatment. These conditions lead to a worse outcome for participant's health.

\section{References}

[1] World Health Organization, "Global Report on Diabetes," 2016. [Online]. Available: http://www.who.int/about/licensing/.

[2] P. Saeedi et al., "Global and Regional Diabetes Prevalence Estimates for 2019 and Projections for 2030 and 2045: Results from the International Diabetes Federation Diabetes Atlas, 9th edition," Diabetes Res. Clin. Pract., vol. 157, p. 107843, 2019, doi: 10.1016/j.diabres.2019.107843.

[3] Diabetes Federation International, "IDF Diabetes Atlas Ninth edition 2019," 2019. [Online]. 
Available: http://www.idf.org/about-diabetes/facts-figures.

[4] Kemenkes RI, "Laporan Nasional Riset Kesehatan Dasar," 2018.

[5] Dinas Kesehatan Kabupaten Boyolali, "Kabupaten Boyolali Tahun 2014,” 2014.

[6] C. Kim, "Does menopause increase diabetes risk? Strategies for diabetes prevention in midlife women," Women's Heal., vol. 8, no. 2, pp. 155-167, 2012, doi: 10.2217/whe.11.95.

[7] I. Subramaniam and J. L. D. Gold, "Diabetes Mellitus in Elderly - An Overview," Indian J. Endocrinol. Metab., no. February, pp. 744-752, 2015.

[8] Organisation for Economic Co-operation and Development (OECD), "Measuring Women ' $\mathrm{S}$ Economic Empowerment," no. 16, 2019.

[9] J. W. Hill, The World's Women 2015 Trends and Statistics, vol. 14, no. 5. 1978.

[10] Kementerian Pemberdayaan Perempuan dan Perlindungan Anak, "Profil Perempuan Indonesia 2019."

[11] L. Schweyer, "Diabetes and Quality of Life,” Worls J. Diabetes, vol. 8, no. 4, pp. 121-129, 2017, doi: 10.1016/j.revinf.2015.02.017.

[12] P. I. Pera, "Living with Diabetes: Quality of Care and Quality of Life," Patient Prefer. Adherence, vol. 5, pp. 65-72, 2011, doi: 10.2147/PPA.S16551.

[13] R. E. Rayanti, N. S. Wariunsora, S. P. Soegijono, U. Kristen, and S. Wacana, "The psychosocial responses and coping strategies of diabetes mellitus type 2 patients of the Ambon culture dengan budaya Ambon," Masyarakat, Kebud. dan Polit. J., vol. 31, no. 4, pp. 389-399, 2016.

[14] M. A. McCoy and L. A. Theeke, "A systematic review of the relationships among psychosocial factors and coping in adults with type 2 diabetes mellitus," Int. J. Nurs. Sci., vol. 6, no. 4, pp. 468-477, 2019, doi: 10.1016/j.ijnss.2019.09.003.

[15] D. Pitaloka and E. Hsieh, "Health as submission and social responsibilities: Embodied experiences of Javanese women with type II diabetes," Qual. Health Res., vol. 25, no. 8, pp. 1155-1165, 2015, doi: 10.1177/1049732315577607.

[16] A. M. Huda, "The Identity of Javanese Women," JARES, vol. 1, no. 1, p. 41, 2016.

[17] Matthew B. Miles and A. Michael Huberman, Qualitative data analysis: a methods sourceboo. 316AD.

[18] W. H. Polonsky and R. R. Henry, "Poor medication adherence in type 2 diabetes: Recognizing the scope of the problem and its key contributors," Patient Prefer. Adherence, vol. 10, pp. 1299-1306, 2016, doi: 10.2147/PPA.S106821.

[19] J. J. Marín-Peñalver, I. Martín-Timón, C. Sevillano-Collantes, and F. J. del Cañizo-Gómez, "Update on the treatment of type 2 diabetes mellitus," World J. Diabetes, vol. 7, no. 17, p. 354, 2016, doi: 10.4239/wjd.v7.i17.354.

[20] L. Falco, G; Pirro, PS; Castellano, E; Anfossi, M; Borretta, G; Gionotti, "The Relationship between Stress and Diabetes Mellitus," J. Neurol. Psychol., vol. 3, no. 1, pp. 1-7, 2015, doi: 10.13188/2332-3469.1000018.

[21] A. Yamin and C. W. M. Sari, "Relationship of Family Support Towards Self-Management and Quality of Life of Patients with Type 2 Diabetes Mellitus," J. Keperawatan Padjadjaran, vol. 6, no. 2, pp. 175-182, 2018, doi: 10.24198/jkp.v6i2.673.

[22] L. Parker and H. Creese, "The Stigmatisation of Widows and Divorcees (janda) in Indonesian Society," Indones. Malay World, vol. 44, no. 128, pp. 1-6, 2016, doi: 10.1080/13639811.2015.1111647.

[23] R. Marianti, "Support Support for Widows in Malang, East Java," University of Amsterdam, 2020. 